\title{
Metastatic choriocarcinoma in the thoracic extradural space: case report
}

\author{
Etem Beşkonakli ${ }^{1}$, Süleyman Cayli ${ }^{1}$ and Sezer Kulaçoğlu ${ }^{2}$ \\ Departments of ${ }^{1}$ Neurosurgery and ${ }^{2}$ Pathology (SK), Numune Hospital, Ankara-Turkey
}

\begin{abstract}
A case is reported of a 44-year-old woman with metastatic choriocarcinoma of the thoracic extradural space causing paraplegia. Spinal cord compression due to an extradural deposit is an emergency in neurosurgical practice. The majority of these lesions are metastatic. To our knowledge choriocarcinoma metastases and extradural cord compression in the spinal canal is the first case reported in the neurosurgical literature.
\end{abstract}

Keywords: choriocarcinoma; spinal cord compression; metastases; paraplegia

\section{Introduction}

It has been estimated that $5 \%$ of cancer patients have spinal extradural metastases although all extradural metastases are not clinically evident. ${ }^{1}$ In general metastatic invasion of the spinal axis is mainly osseous secondarily extradural. According to many published series, the majority of the metastases originate from lung, breast and lymphoma but in some cases the original site of the tumor could not be detected. ${ }^{1-3}$ Female genital lesions including uterine and ovarian lesions play a minor role for metastases in the spinal extradural region. ${ }^{2,4}$ The metastases usually occur via the paravertebral and extradural venous plexus, or by direct invasion. The effects of such extradural lesions are mainly vascular obstruction, extravasation, neural oedema, medullary ischaemia and infarction. ${ }^{5,6}$

\section{Case report}

A 44-year-old woman was admitted to our department in June 1989 with a 10-day history of difficulty in walking and urinary incontinence. There was a history of total hysterectomy for uterine choriocarcinoma 2 years previously. She had remained clinically free of any evidence of this disease for 2 years.

On several physical examinations no abnormality was found, but neurological examination revealed paraplegia, loss of urinary bladder sphincter control, impaired sensation and loss of all deep tendon reflexes below the level of thoracic $6\left(\mathrm{~T}_{6}\right)$. There were no other abnormalities in the central nervous system. Plain Xrays of the spine and chest were normal, but myelography showed a complete block with intact bony structures at $T_{5}$ level. Pelvic ultrasonography and gynaecological consultation confirmed total hysterectomy but other findings were normal. Laboratory data showed normal serum electrolytes, blood haemoglobin

Correspondence: Dr. Etem Beşkonakli, Mertler sokak 41/6 Beştepe 06510 Ankara. Turkey and haematocrit levels, and normal renal and liver function tests.

At operation a total laminectomy at $\mathrm{T}_{4-6}$ level was performed. An extradurally located tumour mass causing compression of the spinal cord was noted and dissected and gross total removal was achieved. The tumour appeared blackish brown in colour, was relatively soft and easily removed from the dura mater. Microscopically the tumour consisted of multinuclear syncytiotrophoblastic cells with large eosinophilic cytoplasm around the mononuclear cytotrophoblastic cells. A large necrotic area was also present (Figure 1). These findings were consistent with choriocarcinoma and a diagnosis of metastatic choriocarcinoma in the spinal extradural space was made. After surgery the neurological condition did not change. Postoperative laboratory investigation revealed B-HCG $1720 \mathrm{MIU} / \mathrm{ml}$ with other normal blood studies. On the 10th postoperative day the patient transferred to the oncology hospital for medical treatment but died from bronchopneumonia 5 months later.

\section{Discussion}

Choriocarcinoma most often originates in the trophoblastic tissue of a hydatidiform mole but may also originate from the germinal epithelium of testes, ovary or a normal placenta and rarely, as a complication of gestational choriocarcinoma. Hydatidiform mole is thought to be a benign disease but choriocarcinoma develops in $1 \%$ of these patients. ${ }^{7,8}$ The disease is mostly encountered in elderly women and older pregnant women. The prognosis is considered to be very poor. Metastases often develop early and are generally haematogenous because of the affinity of trophoblasts for blood vessels. ${ }^{9}$ The latent period may be long as in our case where the disease was diagnosed 2 years after a previous hysterectomy. ${ }^{10}$ The most common sites for metastases are lung, liver and brain 


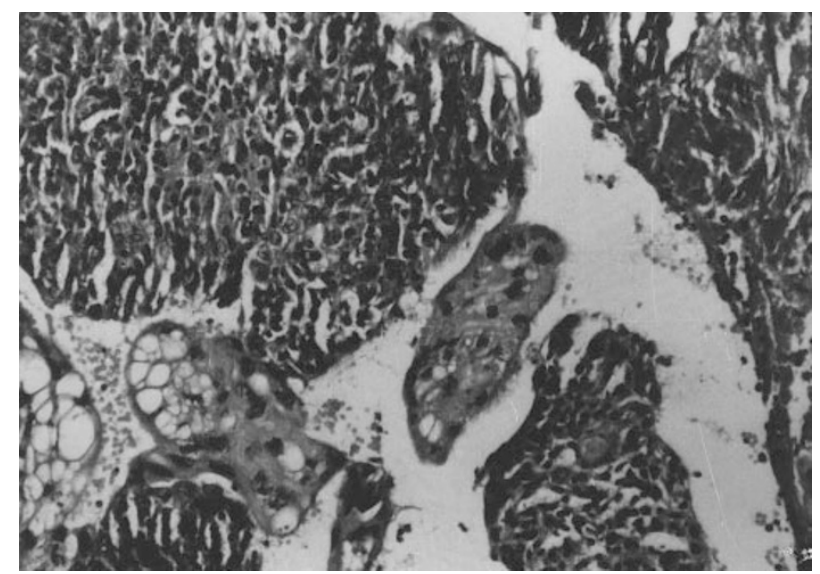

Figure 1 Histopathological view of the tumour showing trophoblastic cells $(\mathrm{HE} \times 100)$

and the less reported sites are skin, bones, gastrointestinal tract, breast and kidney. ${ }^{7,11-14}$

This report presents an unusual case of metastatic choriocarcinoma in the spinal extradural space. Although one case was reported in the gynaecological literature we have not been able to find any reported case in the neurosurgical literature. ${ }^{15}$ For the preoperative diagnosis myelography was used because CT and MRI were not available at that time. The diagnosis was made by clinical history, myelography, laboratory tests and histopathological examination. Finally when a spinal extradural mass is encountered, the possibility of metastatic gynaecological disease should be borne in mind especially in fertile female patients.

\section{References}

1 Brihaye J, Ectors P, Lemort M, Houtte PV. The management of spinal epidural metastases. Advances and Technical Standards in Neurosurgery 1988; 16: 121-176.

2 Dunn RC, Kelly WA, Wohns RNW, Howe JF. Spinal epidural neoplasia. A 15 year review of the results of surgical therapy. $J$ Neurosurg 1980 52: $47-51$.

3 Young RF, Post EM, King GA. Treatment of Spinal Epidural Metastases. Randomized prospective comparison of laminectomy and radiotherapy. J Neurosurg 1980; 53: 741-748.

4 Kretschmer H. Spinal metastases as the cause of acute and subacute transverse spinal cord paralysis. Neurosurg Rev 1979; 2: $117-124$.

5 Ikeda H, Ushio Y, Hayakawa T, Mogami H. Oedema and circulatory disturbance in the spinal cord compressed by epidural neoplasms in rabbits. J Neurosurg 1980; 52: 203-209.

6 Kato A et al. Circulatory disturbance of the spinal cord with epidural neoplasm in rats. J Neurosurg 1985; 63: 260-266.

7 Begent RHJ. Trophoblastic disease. In Shepherd JH, Monogham JM (eds) Clinical Gynaecological Oncology 1st ed. Oxford Blackwell Scientific Publications, pp. 244.

8 Chandra SA et al. Neonatal intracranial choriocarcinoma. Arch Pathol Lab Med 1990; 114: 1078 - 1082.

9 Olive DL, Lurain JR, Brewer JI. Choriocarcinoma associated with term gestation. Am J Obstet Gynecol 1984; 148: 715.

10 Ledermann JA, Crawford SM, Philip PA, Bagshawe KD. Curable metastatic cancer in young women. Br Med J 1987; 299: 432 - 433.

11 Bakri YN, Pedersen P, Ezzat A. Metastatic choriocarcinoma with coexistent term pregnancy following four recurrent consecutive moles. Acta Obstet Gynecol Scand 1992; 71: 401-403.

12 Dautenhahn L, Babyn PS, Smith CR. Metastatic choriocarcinoma in an infant: imaging appearance. Pediat Radiol 1993; 23: $597-600$.

13 Kawakami Y et al. Primary intracranial choriocarcinoma. $J$ Neurosurg 1980; 53: 369-374.

14 Vani R, Kuntal R, Koteshwar RK. Choriocarcinoma following term pregnancy with bone metastasis (letters). Int J Gynecol Obstet 1993; 40: $252-253$.

15 Kuten A et al. Pregnancy and delivery after successful treatment of epidural metastatic choriocarcinoma. Gynecol Oncol 1978; 6: $464-466$. 